\title{
Life Insurance in the UK: The Role of the Actuary and the Single Market
}

\author{
by Steven Haberman*
}

\section{Introduction}

The purpose of this working paper is to provide an outline of the British life insurance environment, with particular emphasis on the role of the actuary. The description and subsequent discussion are used to initiative consideration of issues that are likely to be important for the comparisons of insurance practice and performance across national boundaries, with the advent of the Single Market in Insurance.

\section{Methods of supervision}

1.1. In the member states of the EC, insurance business is supervised by one or more of the following means:

(i) statute (Acts and associated Regulations);

(ii) professional codes of conduct; and

(iii) industry codes of practice.

The balance between these supervisory methods varies markedly between countries, but the fundamental objective of all supervisory regimes is the protection of the policyholder - i.e. the consumer.

Protection of the consumer is generally achieved:

(i) by establishing and monitoring minimum standards of financial management and solvency;

(ii) by defining acceptable standards and styles of marketing; and

(iii) by ensuring, as far as possible, that the consumer is properly and adequately advised as to the nature of the product being purchased.

1.2. In the United Kingdom, statutory supervision is carried out by the Department of Trade and Industry ("DTI"), the Registry of Friendly Societies („Registry”) and the

\footnotetext{
* Department of Actuarial Science and Statistics, City University, London.
} 
Securities and Investments Board ("SIB") and its associated self-regulatory organisations established by the Financial Services Act 1986: primarily the Life Assurance and Unit Trust Regulatory Organisation ("LAUTRO") and Investment Management Regulatory Organisation ("IMRO").

Professional supervision is carried out by a number of professional bodies whose members are involved in insurance business, most notably the Institute of Actuaries, the Faculty of Actuaries and the Institute of Chartered Accountants in England and Wales.

Industry supervision is carried out by a variety of industry bodies and trade associations, e.g. the Association of British Insurers, the Council of Lloyds.

1.3. An important element in the UK's supervisory regime is the Government Actuary's Department ("GAD") which is a branch of government and the civil service and can be regarded as a consulting actuary to government. Inter alia, GAD advises the DTI and the Registry on matters relating to insurance business. The normal routine of GAD, in this advisory capacity, focuses on the receipt and scrutiny of annual returns from life and nonlife companies. (See section 3).

1.4. The British approach has been described as a "double harness" system with the regulatory authorities and the actuarial profession pulling together (in the same direction!) and with significant responsibilities delegated to the actuarial profession.

1.5. The approach in the UK has thus been to avoid detailed, all embracing regulations and instead to focus on principles in statute. As will be seen, the framework depends on the existence of a strong actuarial profession with a strong professional code and associated guidance (including disciplinary procedures).

1.6. The power to interpret and apply the principles in practice is delegated to the " $A p$ pointed Actuary", a role introduced by the Insurance Companies (Amendment) Act 1973. This position is defined by statute and has to be carried out by a Fellow of the Institute of Actuaries (England and Wales) or Faculty of Actuaries (Scotland). (Special arrangements have been made for actuaries with overseas qualifications to act as an Appointed Actuary for a United Kingdom branch of an overseas company). The Appointed Actuary to a UK life insurance company is either employed by the company or is a consultant. In either case, he (or she) would be regularly involved in the financial affairs of the office.

The main purpose behind the introduction of the concept of the "Appointed Actuary" was to upgrade the actuary from someone who carried out a valuation of the assets and liabilities every year to an identifiable professional within the company's management who could monitor the financial state of the company on a continuous basis.

An Appointed Actuary is expected to be able to carry many responsibilities at the same time. He has responsibility for calculating the mathematical reserves in respect of the life business and for ensuring the continuing financial viability of the company. He has a major role to play in protecting the "reasonable expectations" of policyholders (see section 5). The Appointed Actuary should be kept fully informed of all relevant matters relating to the company's financial status including premium rates, investment policy, reinsurance arrangements, distributions of profit to policyholders and shareholders. He should have direct access to the company's Board of Directors and should be included in all discussions relating to the company's future financial position. Not only should the Appointed Actuary be a member of the company's financial management team, but he also has important obligations to the supervisory authorities. 
It is essential for the working of the system that the Appointed Actuary is allowed power independent of the company in order to express, if necessary, concerns about a course of action which might jeopardise the company's security. If not satisfied, the Appointed Actuary must report the position to the DTI. These responsibilities are spelt out in the Institute of Actuaries' professional guidance notes.

The Appointed Actuary system also operates in Ireland. The role of the actuary in life assurance in most other member states of the EC is defined more narrowly, however.

1.7. Responsibility in the UK is thus delegated to the Appointed Actuaries and, through them, to the professional bodies. The profession is then able to consider and issue further guidance to members which amplifies the statutory framework. Members are bound to follow such guidance, so this is as effective as statute, provided that the profession's disciplinary procedures are adequate. However, unlike statute, changes to professional guidance notes can be made relatively easily, thus allowing the rules to be kept up to date with changes in the environment. Professional guidance also ensures that supervisory monitoring by the Appointed Actuary is continuous, rather than being carried out once a year through a perusal of the statutory returns to the supervisory authorities.

1.8. Within the UK statutory framework, substantial discretion is given to the Appointed Actuary and to the managers of the business with regard to premium rates, product design, reserving bases, surrender bases and other factors.

The DTI (and GAD) would be involved in the initial authorization of companies (and subsequent authorization of new classes of business) and in carrying out an annual scrutiny of the prescribed and detailed returns which show the company's financial position at a point in time.

GAD carry out a full examination of these annual returns, the objectives of which are twofold:

(i) to check that the appropriate Acts and Regulations have been complied with; and

(ii) to look at the company dynamically, by which is meant an assessment of the way in which the financial state of the company is developing.

If the examination should show up any problems, these would be discussed with the company, and GAD would play a part, often a major part, in such discussions.

A recent development has been the introduction of a programme of visits by staff from the GAD and DTI to life companies. Usually, this involves a representative from GAD and one from DTI and includes meetings with the Appointed Actuary, the chief executive and other senior executives. The main purpose of such a visit is to discuss the company's future strategy, management issues including the role of the Appointed Actuary as well as any points outstanding between the company and the supervisory authorities.

1.9. Actuaries also play an important supervisory role elsewhere. Thus, SIB and LAUTRO have actuaries on their boards of management and also employ their own actuaries and LAUTRO also makes use of an actuarial advisory panel. The major areas of activity of these actuaries are advice on interpretation and preparation of new rules for selling practices and product disclosure, and assistance with the monitoring of rules.

1.10. Further, there are a number of industry codes of practice issued by the Association of British Insurers and the Council of Lloyds. 
1.11. It should be noted that, despite the existence of long-developed and working codes of practice in the UK, the Financial Services Act 1986 created a self-regulatory regime which has adopted detailed statutory regulations to enforce various codes of practice: hence, the role of SIB, LAUTRO, IMRO and so on.

1.12. The level of supervisory control influences the whole nature of the insurance industry within a country. The freer the control, the wider tends to be the range and diversity of products and hence the choice to the consumer. But, it could be argued, the freer the control, the greater the risk to the consumer that his contractual obligations might not be fulfilled because of the financial inadequacies of the insurer.

The UK philosophy would be that if minimum standards of solvency are prescribed and policed, and if the professional managers of the industry, including actuaries in particular, have high levels of technical expertise and high and strong professional standards, then the risk of contractual obligations not being fulfilled should be minimal while consumer choice is maintained. A flexible system that depends critically on actuarial discretion can cope with a diverse market and a swiftly changing investment environment, as is the case in the UK.

\section{Premium rates and product design}

2.1. In the UK, there is considerable freedom in the design of life insurance products. There is no regulatory standardisation of product terms or conditions. In the UK, premium rates and the design of life insurance products are determined by each company, subject to the following constraints:

(i) As noted in the previous section, in order to become authorised, a new insurance company must, inter alia, submit details to the DTI of the technical bases for calculating premium rates which the Appointed Actuary to the company proposes to employ for each class of business. The other information supplied to the DTI would allow the supervisory authority to assess the adequacy of the proposed premium bases.

(ii) Authorization can be withdrawn from a company or the authorities can intervene in the affairs of a company if there exist grounds for protecting policyholders or potential policyholders against the risk that the company may be unable either to meet its liabilities or to fulfil the "reasonable expectations" of policyholders. Inadequate premium rates would presumably constitute such grounds.

(iii) Guidance Note 1 ("GN 1") was issued by the Councils of the Institute and Faculty of Actuaries as guidance to the professional responsibilities of Appointed Actuaries, but all actuaries responsible for long term insurance business are expected to follow the same principles. The profession regards it as the Appointed Actuary's duty to take all reasonable steps to ensure that he is, at all times, satisfied that if he were to investigate and report on the financial condition of the company, the position would be satisfactory. GN1 states that the financial condition of the company is particularly affected by, inter alia, the premium rates on which existing business has been and current new business is being written. It is the Appointed Actuary's duty to advise the company as soon as he is of the view that a course of action is being, or is proposed to be, followed which seems likely to lead him to withhold subsequent actuary's certificates (as requested by legislation) in the normal form. (Such a state of affairs 
could not be construed as a satisfactory position). If the company persists in following such a course of action, it is also his duty to advise the DTI, after so informing the company.

2.2. It is clear from the constraints described above that the actuary plays an important role in the determination of a company's premium rates. However, a life insurance company could, and often does, choose to divide the actuarial input to premium rates between at least two actuaries, the "marketing actuary" or "product development actuary", and the Appointed Actuary.

Because premium rates are not determined by law or regulation or by cartel, and because of the freedom of action of the actuary within his professional code of conduct, there is scope for innovative design, and the actuary - Appointed Actuary or marketing actuary, or both - does play a very significant role in innovative product design.

2.3. Disclosure of information is an implicit, important aspect in the UK life insurance environment. It can be argued that freedom has encouraged competition and permitted greater degree of consumer choice. In order for this to be effective, consumers either need access to information on product terms and conditions in a comprehensible form so that they can exercise the choice themselves or they need access to sound advice on what products are available. The UK life insurance market features two types of intermediary providing such advice: the independent intermediary and the exclusive (or "tied") agent.

In an environment of independent intermediaries required to know their customer and to give "best advice" suited to each individual's particular needs, this element of consumer choice is real. Even if the consumer cannot identify the significance of differences in product design, the independent intermediary should be able to help him do so or to exercise judgement on behalf of a particular consumer.

A more limited consumer choice exists with exclusive agents, yet even here the agent should have an obligation to match product to customer and disclose product information in order to help the customer to understand what is being bought or to ask further questions.

2.4. In the UK, there is also freedom of investments for insurance companies. This freedom, coupled with the acceptance by the consumers of risk investments, has led to the practice of insurers investing heavily in ordinary shares and property and has resulted in enhanced returns for policyholders. Since this practice involves substantial amounts of unrealised capital appreciation on the ordinary share and property investments, policyholders have only been able to benefit because accounting systems have permitted this appreciation to be recognised and because bonus systems have evolved via the introduction of terminal bonuses to provide equity between policyholders and to distribute the surplus (see sections 3 and 4 ).

2.5. However, a corollary of risk investments serving the long-term interests of the consumer seeking the best return at maturity is that it is inconsistent with guaranteed surrender values. As a result, policyholders terminating their contracts early are unlikely to have received an adequate return. A system with no constraints on policy design may thus disadvantage one group of consumers, although the development in recent decades in the UK of unit-linked policies has gone some way to remedy this perceived deficiency of conventional life insurance policies. 
A surrender value basis which is required to be consistent with the premium basis has an element of simplicity but it results in guaranteed surrender values. In changing times, this is tenable only if the bases chosen are conservative and there is severely constrained investment policy. A more flexible approach, as in the UK, would allow those consumers seeking the best long-term return to choose policies without guaranteed surrender values which would hold out the prospect of substantially higher maturity values than those with guaranteed surrender values.

2.6. The nature of premium rates and product design in a particular life insurance market depends on a wide range of factors: these include the supervisory system, status and role of the actuarial profession, contract law, premium taxation, taxation of insurance companies, investment markets available, currency movements and restrictions, policy terms and conditions prevailing, methods of selling products.

2.7. There is currently a wide variation between premium rates for comparable policies in the different market of the EC. The most competitive markets have the lower premium rates. There are other benefits associated with a more competitive, more liberal environment.

2.8. Thus, in relation to product design, consumers are not all the same and different products are required to satisfy different needs. Given that the world is changing, innovation in product design is in the interest of consumers and helps to keep insurance companies alive to the needs of their market. Insurance products do not exist in isolation and they have changed in response to influences such as legislation, consumer attitudes, technology, types of investment available to the insurers and the advent of new risks, for example AIDS. These changes have been most marked in markets such as the UK and Ireland where maximum freedom exists; however, many markets are now responding to changing consumer demands. For example, attitudes to risk vary across Europe. Many consumers have traditionally been risk averse. Yet, as capital markets become more accessible, attitudes change and, in this context, unit-linked products may be able to give the consumer a wider investment choice.

2.9. The diversity of the British life insurance market relative to the markets in continental Europe is illustrated by Table 1, which indicates the degree of concentration and level of competition for various countries. Table 1 shows that the largest life insurance companies occupy a less dominant position in Great Britain than in other markets in Europe and elsewhere (e.g. the largest ten companies have a market share equivalent to $47 \%$ by premium income), with the notable exception of the United States.

\section{Reserving for liabilities}

3.1. The approach to the supervision of reserving for life insurance in the UK is based on what might be called "Broad Regulation". This makes use of a statutory minimum standard, with control based around the concept of "freedom with disclosure".

Detailed annual returns are required from insurance companies setting out all aspects of the reserving methods and bases used, together with the data (i. e. a statement of the business in force) and the results obtained. These returns are publicly available and the objective is that they should contain sufficient information to allow an independent 
Table 1:

Distribution of market shares in life insurance by premium income

Percentage market share by premium income:

Leading insurers by Ranks

Ranks

Size of life

Life insurance

market *

\begin{tabular}{|c|c|c|c|c|c|c|c|c|}
\hline $\begin{array}{l}\text { EUROPEAN } \\
\text { COMMUNITY }\end{array}$ & Year & $1-3$ & $4-5$ & $6-10$ & $11-15$ & $1-10$ & $\underset{\text { millions }}{\text { US }}$ & $\begin{array}{c}\text { World } \\
\text { Share of } \\
\text { Market \% }\end{array}$ \\
\hline Great Britain & 1987 & 23.5 & 8.5 & 15.0 & 12.0 & 47.0 & 65,645 & 9.3 \\
\hline Denmark & 1987 & 54.0 & 16.9 & 19.6 & $\begin{array}{c}\text { Not } \\
\text { Known }\end{array}$ & 90.5 & 2,600 & 0.4 \\
\hline France & $\begin{array}{l}1986 \\
1989\end{array}$ & $\begin{array}{l}38.9 \\
33.3\end{array}$ & $\begin{array}{l}11.9 \\
14.1\end{array}$ & $\begin{array}{l}15.3 \\
20.7\end{array}$ & $\begin{array}{r}8.5 \\
10.2\end{array}$ & $\begin{array}{l}66.1 \\
68.1\end{array}$ & 39,081 & 5.5 \\
\hline Greece & 1987 & 71.5 & 10.5 & 12.2 & $\begin{array}{c}\text { Not } \\
\text { Known }\end{array}$ & 94.2 & 437 & 0.1 \\
\hline Ireland & 1987 & 58.5 & 11.5 & 15.8 & $\begin{array}{c}\text { Not } \\
\text { Known }\end{array}$ & 85.8 & 2,565 & 0.4 \\
\hline Italy & $\begin{array}{l}1987 \\
1989\end{array}$ & $\begin{array}{l}51.2 \\
52.1\end{array}$ & $\begin{array}{l}13.8 \\
12.4\end{array}$ & $\begin{array}{l}13.2 \\
13.9\end{array}$ & $\begin{array}{l}7.1 \\
7.4\end{array}$ & $\begin{array}{l}78.2 \\
78.4\end{array}$ & 7,665 & 1.1 \\
\hline Netherlands & $\begin{array}{l}1986 \\
1989\end{array}$ & $\begin{array}{l}45.8 \\
41.9\end{array}$ & $\begin{array}{l}12.5 \\
11.0\end{array}$ & $\begin{array}{l}15.6 \\
17.5\end{array}$ & $\begin{array}{l}5.6 \\
8.5\end{array}$ & $\begin{array}{l}73.9 \\
70.4 \\
\end{array}$ & 12,474 & 1.8 \\
\hline Portugal & 1987 & 32.8 & 18.1 & 33.3 & $\begin{array}{c}\text { Not } \\
\text { Known }\end{array}$ & 84.2 & 518 & 0.1 \\
\hline Spain & $\begin{array}{l}1987 \\
1989\end{array}$ & $\begin{array}{l}53.6 \\
51.7\end{array}$ & $\begin{array}{l}9.2 \\
6.6\end{array}$ & $\begin{array}{l}14.9 \\
11.9\end{array}$ & $\begin{array}{l}6.7 \\
8.8\end{array}$ & $\begin{array}{l}77.7 \\
69.3\end{array}$ & 4,688 & 0.07 \\
\hline West Germany & $\begin{array}{l}1987 \\
1989\end{array}$ & $\begin{array}{l}26.3 \\
25.4\end{array}$ & $\begin{array}{l}7.6 \\
7.9\end{array}$ & $\begin{array}{l}14.6 \\
14.6 \\
\end{array}$ & $\begin{array}{l}11.2 \\
10.9 \\
\end{array}$ & $\begin{array}{l}48.5 \\
47.9 \\
\end{array}$ & 35,585 & 5.0 \\
\hline \multicolumn{9}{|l|}{ OTHERS } \\
\hline Austria & $\begin{array}{l}1987 \\
1989\end{array}$ & $\begin{array}{l}39.4 \\
36.4\end{array}$ & $\begin{array}{l}15.9 \\
16.6\end{array}$ & $\begin{array}{l}19.9 \\
19.8\end{array}$ & $\begin{array}{l}11.6 \\
11.6\end{array}$ & $\begin{array}{l}75.2 \\
72.8 \\
\end{array}$ & 2,584 & 0.4 \\
\hline Canada & 1987 & 29.3 & 12.5 & 20.6 & 11.7 & 62.4 & 16,006 & 2.3 \\
\hline Japan & $\begin{array}{l}1987 \\
1989\end{array}$ & $\begin{array}{l}46.9 \\
42.2\end{array}$ & $\begin{array}{l}15.0 \\
15.3\end{array}$ & $\begin{array}{l}22.1 \\
23.5\end{array}$ & $\begin{array}{l}11.5 \\
13.5\end{array}$ & $\begin{array}{l}84.0 \\
81.0\end{array}$ & 203,279 & 28.7 \\
\hline Switzerland & $\begin{array}{l}1987 \\
1989\end{array}$ & $\begin{array}{l}58.7 \\
58.1\end{array}$ & $\begin{array}{l}16.4 \\
15.6\end{array}$ & $\begin{array}{l}13.9 \\
14.5\end{array}$ & $\begin{array}{l}7.9 \\
8.0\end{array}$ & $\begin{array}{l}89.0 \\
88.2\end{array}$ & 10,971 & 1.6 \\
\hline USA & $\begin{array}{l}1987 \\
1989\end{array}$ & $\begin{array}{l}15.1 \\
19.4\end{array}$ & $\begin{array}{l}4.7 \\
5.3\end{array}$ & $\begin{array}{l}8.0 \\
9.8\end{array}$ & $\begin{array}{l}6.0 \\
6.9 \\
\end{array}$ & $\begin{array}{l}27.8 \\
34.5\end{array}$ & 205,756 & 29.1 \\
\hline
\end{tabular}

* denotes size of market by premium income at end of 1990 .

Sources: Sigma 12/89. Insurers' Market Shares in 12 countries.

Sigma 1/92. The Largest Insurance Companies in 10 countries.

Sigma 4/92. World Insurance in 1990.

Post Magazine. October 19, October 26, November 21989. 
observer to reassess the results obtained. This principle has been in operation in the UK from the beginnings of life insurance supervision in 1870 .

Under a regime of broad regulation, the actuary might choose to use a basis which is stronger in some respects than the statutory minimum, thereby creating implicit margins.

There are risks in this "Broad Regulation" approach. If only general principles are specified in statute, a strong actuarial profession is needed in order to ensure that suitable standards are maintained. This should then reduce the risk that too liberal an interpretation would be placed on the statutory principles, which may lead to the policyholders incurring a loss.

3.2. In the UK, a second level of control is then provided by the DTI (Insurance Division) which is responsible for the monitoring of insurance business carried out in the UK. With respect to reserving, the DTI carries out this responsibility by scrutinising the returns provided by each company. GAD advises the DTI whether they should take any action, and the DTI has various levels of intervention in the business of insurers that it may invoke, ranging from informal discussions with the Appointed Actuary to requiring the company to cease writing new business. There is a close relationship between the actuarial profession and GAD, with joint working parties of the Institute, Faculty and GAD set up to consider issues of mutual interest, such as possible changes to the reserving regulations.

3.3. Further protection to consumers in the UK is provided by the Policyholders Protection Act 1975 . Broadly, this limits the reduction in guaranteed benefits that can be suffered by a policyholder to $10 \%$, subject to a proviso that allows larger reductions if the benefits promised are deemed to have been "excessive". To finance claims under the scheme, which covers both life and general insurance business, a levy is made on all companies based on their premium income. Since 1975 , it has only once been found necessary to impose a levy to assist the policyholders of a life insurance company in financial difficulties.

3.4. Mathematical reserves are prepared by each company and certified by the Appointed Actuary subject to the following constraints.

(i) The Insurance Companies Regulations 1981:

- set out statutory margins of solvency, in compliance with the solvency margin provisions of the EC Life Establishment Directive 1979;

- require that the liabilities shall be valued on actuarial principles and on prudent assumptions in regard to the relevant factors; and

- require that the amount of the liabilities shall, in the aggregate, not be less than the amount calculated in accordance with the regulations.

(ii) The minimum valuation basis in the Regulations makes provisions for:

- account to be taken for the nature and term of the assets;

- the avoidance of future valuation strain;

- the way in which valuation premiums are determined;

- allowance for acquisition expenses;

- the maximum rates of interest;

- the appropriate rates of mortality;

- the calculation of expenses reserves;

- the allowances to be made for options; 
- the treatment of negative liabilities; and

- the allowance to be made for voluntary discontinuance.

In many of the provisions described above, significant discretion is allowed to the actuary as to methods and assumptions. The Appointed Actuary is required to ensure that the mathematical reserves are at least as great as those indicated by this minimum valuation basis. The requirements are amplified by Guidance Note 8 ("GN 8") issued by the Councils of the Institutc and Faculty of Actuarics.

3.5. The Insurance Companies Act 1982 requires evcry insurance company to which it applies to cause an investigation to be made into its financial condition, once in each year, by the Appointed Actuary.

The Insurance Companies (Accounts and Statements) Regulations 1983 require the Appointed Actuary to prepare a valuation report which must cover at least the information stated in the Regulations. In addition, the same Regulations require the Appointed Actuary to certify that proper records have been kept, and that the mathematical reserves and liabilities are adequate and comply with the Regulations.

The professional guidance, however, goes further than the formal requirement to carry out a valuation once a year. The Appointed Actuary's duty is considered as having to monitor the company's financial condition on a continuous basis. Thus GN 1 states that the Appointed Actuary is to take all reasonable steps to ensure that he is, at all times, satisfied that, if he were to carry out an actuarial valuation, then the position would be satisfactory.

\section{Valuation of assets and company accounts}

4.1. In general, insurance company accounts and statements are prepared for three different audiences through three separate statements:

(a) shareholders, policyholders and the general public through the published accounts of the insurance company;

(b) the government supervisory body through returns to that body;

(c) the government body that is responsable for taxation, through returns to that body.

The definitions and requirements may differ between countries and thus these three statements may be completely or partly different. If it were the practice in a particular country for the published accounts to be used for one of the other purposes, supervisory or taxation, then it is important to understand how changes in the prescribed format of company accounts may affect the actual business of the life insurance company, for example in taxation, investment policy or bonus distribution.

4.2. In the UK, insurance companies are able to draw up their accounts in accordance with Schedule 9 of the Companies Act 1985, under which the accounting and disclosure requirements are less demanding and detailed than would apply generally to companies (Schedule 4). In particular, there are no prescribed formats and insurance companies can take advantage of the exemptions available from some of the disclosure requirements (in Schedule 9), thus allowing them to maintain hidden reserves. Also, if a company does utilise these exemptions, then the Act requires the auditors only to state whether, in their opinion, the accounts had been properly preparcd relative to the Act: so the auditors are not required to comment on whether the accounts give a "true and fair view" of the financial status of the insurance company. 
4.3. The value at which assets are included in insurance company accounts varies between countries, and may vary between companies within one country. Partly, this is because there are at least two values which are of importance for any asset on any date: the market value (or some estimate thereof) at that date; and the original cost of that asset. There are other values for particular assets that may also be of relevance: the amortised value (sometimes used for fixed interest stocks with a specific redemption date); the lowest market value reached by the asset between purchase and the balance sheet date; the original cost of assets held previously, which were sold to purchase the present asset (where realised gains have not been brought into account); the partially written up original cost (where some, but not all, unrealised gains have been brought into account); or the notional value (given by a valuation of the asset, for example, on the same basis as the liabilities).

4.4. In the UK, there is a variety of different approaches to the valuation of assets in the presentation of accounts. Some insurance companies show all assets at current market values, some at historic cost and some at an intermediate value.

4.5. The supervisory body's requirements are now such that it is a statutory requirement that assets are shown on a market value basis. This reflects the significant amount of equity and property investment within insurance company funds. The value of these assets has grown substantially in recent years. In some cases, this increase in value would be recognised explicitly by the sale of the asset and it becomes a realised gain. In many other cases, however, the asset remains in the fund so that the gain is unrealised. This is pursued further in sections 5 and 6 .

4.6. It should be noted that the effect of an increase in asset value, ceteris paribus, is a decrease in the rate of interest earned on those assets. The actuary, in determining the rate of interest to be used in calculating the mathematical reserves, would have regard to this decrease (see paragraph 3.4.). There are now statutory restrictions on the rates of interest which may be used in calculating the mathematical reserves: broadly, the valuation rate of interest must not exceed the yield on the fund at market values. There is also now an overall limit on the re-invested rates to be used more than 3 years from the date of valuation.

\section{Distribution of surplus}

5.1. The methods and amounts of profit distribution to conventional with profit policyholders are the responsability of the Directors and are determined by each company, subject to the following constraints.

(i) The method of profit distribution is subject to market constraints. The uniform reversionary bonus system coupled with the terminal bonus system is very widely used in the UK.

(ii) The Insurance Companies Act 1982 prevents the distribution of profits to policyholders unless an investigation of the financial condition of the company has been carried out by its Appointed Actuary.

(iii) Changes to the proportion of total surplus which is allocated to policyholders are controlled by the Insurance Companies Act 1982.

(iv) The DTI have the power to intervene in the affairs of a company if they consider it desirable to protect policyholders or potential policyholders against the risk that the company may be unable to meet the reasonable expectations of policyholders or 
potential policyholders. What constitutes "reasonable expectations" is a subject for current debate and concern amongst many actuaries. It has not been tested in the Courts. In practice, reasonable expectations have been taken to include the future prospects for distribution of profits to policyholders.

(v) The professional obligations of the Appointed Actuary include the duty to take all reasonable steps to ensure that the company will not allocate profits before the Directors of the company have obtained from him (and considered) a written report containing his observations and recommendations on the subjec.

As the constraints above indicate, the Appointed Actuary to the company performs a central role in determining the methods and amounts of profit distribution.

5.2. A peculiarity of the UK system is the statutory differentiation of the Long Term Business Fund from the Shareholders' Funds. The Appointed Actuary is put in the position of being a "guardian" of the long term fund, being professionally required to advise the directors before any transfer of surplus is made to the Shareholders' Funds.

5.3. It is also worth noting that many actuaries in the UK make use of other methods of valuation internally for the financial management of life companies. While the statutory valuation is almost always prepared using a net premium valuation allied to market values of assets, additional investigations will be carried out based on bonus reserve valuations or cash flow projections using model office techniques. These internal valuations will form the basis for the advice given by the actuary to the directors, including advice on the bonuses to be declared.

In practice, the directors will also take market factors into account before making a final decision, but in the event that the directors decided to distribute an amount which the Appointed Actuary considered excessive, he would be obliged, by statute and his professional code, to advise the DTI of the fact. (The DTI are concerned to ensure that companies are not over-distributing as a result of competitive pressures).

5.4. In the UK, it is usual to distribute investment income and realised and unrealised capital gains to policyholders as surplus. This practice has arisen because of the degree of equity investment which creates problems of fairness of distribution of surplus between the various policyholders (at one particular time and between groups of policyholders at different times) as a result of the significant levels of unrealised capital appreciation present in the assets. Clearly, it would be imprudent to distribute all unrealised capital appreciation in any given year. Capital gains which have not been realised could well be reduced in a subsequent year. If all such unrealised gains had previously been distributed, the company would be insolvent. Thus, UK actuaries have adopted the practice of taking credit for a part of the unrealised gains within the market value of assets, when determining the surplus available for distribution.

Non-guaranteed terminal bonuses are used to facilitate the equitable distribution of capital appreciation. Thus, surpluses arising from unrealised capital appreciation could be declared as permanent additions to the sum insured through reversionary bonuses but, because of the uncertainty attached to unrealised capital appreciation, most UK companies would distribute part of this in the form of non-guaranteed terminal bonuses payable on claims within a limited period. The mathematical reserve for such bonuses relates only to the period for which they are declared. Thus, it is important that the value of the assets shown in the accounts be increased in line with the increase in liabilities. 
5.5. Surplus may be also held back under the UK system; the difference is that this is recognised as being a deliberate part of the planned distribution policy of the life insurance company.

5.6. The recent development of unitised with profit policies in the UK is a step towards the methods used in many EC countries of allocating bonus in proportion to reserves, although the amount of surplus is freely determined. The change could be in part due to competitive forces causing the actuary to lock for ways to reduce the valuation strain on with profit business at a time of rapid growth.

5.7. Regulation of reserving exists ultimately to benefit the consumer by reducing the risk of a company becoming unable to meet its liabilities to an acceptably small level. How allembracing do the statutory regulations have to be to achieve this?

There are two main approaches taken to the supervision of reserving:

(i) "Tight Regulation" where most components of the methods and bases to be used are laid down by the supervisory authority. As the rules have to cope with all eventualities, there is a tendency for them to be very detailed and conservative.

(ii) Broad Regulation" where the principles to be adopted and an acceptable minimum standard are laid down. Companies are free to select their own methods and bases subject to a high degree of public disclosure of their actions.

In both cases, it is usual for the actuary to certify the results of the calculations to the supervisory authority; in the second case, this extends to an expression of opinion on the adequacy of the reserves held.

5.8. "Tight Regulation" operates by requiring strong implicit margins within the main valuation parameters, possibly with additional explicit margins against specific contingencies. Many countries using "Tight Regulation" specify that the valuation basis used must be the same as the premium basis, which itself is constrained by regulation. There may be little scope for judgment by the actuary.

As the reserving basis will affect product design, it is likely that "Tight Regulation" will lead to a reduced level of competition within the industry. The philosophy behind "Tight Regulation" could be summarised as attempting to ensure that life insurance companies never fail. The price for this regulation will be reduced choice and possible reduced returns for the consumer.

5.9. Concerning the "Broad Regulation" approach, there are concomitant risks and much depends on the existence of a strong, actuarial profession to ensure the maintenance of the required standards. The philosophy could be summarised as attempting to minimise the risk of damage to a policyholder's guaranteed benefits to an acceptably small level. It can be argued that this would allow better returns to the policyholders, with minimal additional risk (relative to "Tight Regulation").

5.10. It is worth noting that the actuary within the UK system plays a key role in both the areas of reserving and the determination and distribution of surplus.

\section{Investment policy and practice}

6.1. Concerning non-linked life insurance business, there are a number of possible regulatory constraints: 
(i) Definition of what counts as an admissible investment backing the mathematical reserves;

(ii) Constraints on the maximum admissible amounts held in any one investment;

(iii) Constraints on minimum or maximum amounts held in any particular category of investment ;

(iv) Constraints on the currency of the investments.

6.2. In general, EC states are subject to (i) and (ii), with the choice in (i) being particularly liberal in the UK. (iii) also applies to most EC states with the exception of the UK. Generally, the constraints in (iii) are of the form:

- a minimum investment as a percentage of the mathematical reserves in government bonds;

- a maximum investment as a percentage of the mathematical reserves, for other categories of investment.

6.3. No constraint is placed on the investment of assets backing the explicit solvency margin, except in the UK where there is no distinction between the solvency margin and the mathematical reserves.

6.4. It may be argued that the constraints of type (iii) are unnecessary. In particular, forced investment in government bonds could lead to artificially low interest rates and so harm consumer interest. But, other factors must be allowed for, including the practice of granting guaranteed surrender values and the type of regulation being operated.

6.5. Constraints on currency may relate to currency matching. Of course, currency constraints could prevent companies from issuing policies in foreign currencies which might be in demand when freedom of services eventually applies (post 1993).

6.6. Unit-linked business tends to be subject to much less constraint. This reflects the absence of guarantees on investment returns.

6.7. The investment managers of life insurance companies in the $\mathrm{UK}$ are free to invest in any assets they choose (except for assets matching property-linked benefits). However, the Insurance Companies Regulation 1981 specify the admissible values of assets for the purpose of assessing the financial condition of the company. Certain classes of assets will have an admissible value of zero, and other assets will have their value restricted to a maximum amount, expressed as a proportion of the liabilities. Thus, the UK regime is very liberal as regards choice of investment.

The same Regulations specify the permitted assets by reference to which propertylinked liabilities may be determined.

Further, certain types of very speculative linked investment are not permitted e.g. those linked to commodity funds.

6.8. The Appointed Actuary to a company has a professional duty to have information about the existing investments and the continuing investment policy, and he is required to decide whether the investment policy is or could become inappropriate. If this were the case, he must advise the company on the investment policy necessary to protect the policyholders.

The Appointed Actuary is obliged by statute and by the professional code to take into account the nature and term of the assets and the value placed upon them when determining 
the liabilities. He is also required to make appropriate provision for the effects of possible future changes in the value of the assets and GAD has issued quantitative guidelines on this subject.

In determining the rates of interest to use in the valuation of the liabilities, the Appointed Actuary is permitted notionally to apportion assets between different categories of contract.

6.9. As was noted above, Appointed Actuaries in the UK are obliged to take into account investment policy in setting actuarial reserves. They have, therefore, an indirect influence on investment policy since if the Directors of a life company wish to pursue an imprudent investment policy, the Appointed Actuary would be obliged to increase the reserves (for example, to make prudent provision for the potential mismatching of assets and liabilities) to such an extent perhaps as to call into question the technical solvency of the company. In these circumstances, the investment policy would be modified. In practice, this situation is rare. It is much more likely that the Appointed Actuary will set broad guidelines for the major categories of investments, e.g. gilts and equities, together with more detailed requirements in relation to gilts matching guaranteed liabilities.

6.10. The distributions of life insurance company assets by asset type (excluding assets matching unit-linked contracts) for the major EC life insurance markets show considerable variation, with the UK displaying a very high proportion invested in equities compared to the other major countries (including Germany, France, Italy, Spain and Netherlands).

This feature is explained by a number of factors including

(i) regulatory constraints on freedom of investment;

(ii) size of UK stock market;

(iii) regulatory constraints on product design;

(iv) competition between conventional and unit-linked business is well-developed in the UK;

(v) degree of risk averseness of investors;

(vi) taxation of investment income - in some countries such income is either free of tax or taxed at a low rate, while, in the UK, it is currently taxed at $25 \%$.

6.11. On (iii), it should be noted that the UK life insurance market does not "insist" on guaranteed surrender values, which would be difficult to reconcile with a policy of significant investment in equities.

Point (vi) is important in that there is a clear trade-off in the UK between the high gross returns achieved through investment in equities and property and the relatively high tax being levied on investment income. It is not clear whether the policyholder is "better off" within such a regime or in a different regime where there are more constraints on investment but no tax on investment income.

6.12. It should be noted that the responsibilities delegated to the Appointed Actuary in the UK system give him responsibilities and duties in respect of both sides of the balance sheet, viz liabilities and assets. 


\section{Statutory and professional role of actuaries}

7.1. In the previous sections, reference has been made in passing to the statutory and professional role of actuaries in the British life insurance environment. At the risk of repetition, the next few paragraphs mention the key points.

7.2. An actuary for the purposes of the Insurance Companies Act 1982 is defined as a person who is a Fellow of the Institute of Actuaries or of the Faculty of Actuaries and who has attained the age of 30 years. This definition appears in the Insurance Companies (Accounts and Statements) Regulations 1983.

A recent development is that the Appointed Actuary will be required to hold a current practising certificate which would demonstrate that he/she has maintained an adequate level of relevant continuing professional development (CPD).

Within the statutory framework, substantial discretion is given to the actuary ("the Appointed Actuary") appointed under the Insurance Companies Act 1982 with regard to premium rates, product design, reserving bases, surrender bases and other factors. This has been described as the "double harness" system, with the regulatory authorities and the profession pulling together, and with significant responsibilities being devolved to the actuarial profession.

Guidance notes issued by the Institute and Faculty of Actuaries set out detailed professional standards for the Appointed Actuary. In this way, the profession plays a significant role in the supervision of insurance.

Actuaries make up the Councils of the Institute and Faculty of Actuaries. However, the disciplinary procedures include provision for non-actuaries to participate in Disciplinary Tribunals.

7.3. The professional status of the actuary is not independent of statutory responsibility. The statutory responsibility devolved to the actuary in the UK may have been made possible by the existence of a strong profession. Alternatively, the regulatory attitude which recognised that the profession could be given such responsibility may have helped to create a stronger profession. Either way, it can be argued that statutory recognition, professional responsibility and market responsiveness go hand in hand.

7.4. Links between the actuarial professions in the different countries of the $\mathrm{EC}$ have developed positively, especially since the national associations of actuaries in the different countries together formed the Groupe Consultatif in 1978 (i.e. Groupe Consultative des Associations d'Actuaires des Pays des Communauté Européennes). The main purpose of this organisation is to provide a focus for the representational role of the actuarial profession with regard to the Commission of the $\mathrm{EC}$ and other Community institutions.

7.5. The EC Higher Education Diplomas Directive become effective in January 1991. It provides for the mutual recognition of diplomas for the purpose of pursuing a regulated profession in one member state, having qualified in another member state. With this Directive in place, it is likely that the education of the actuary will be subject to pressure to standardise levels of both skill and experience qualifications, particularly if markets and supervisory regimes are at the same time becoming more similar. It is not clear whether the weakest common standards or the strongest examples or a compromise will form the basis for any standards in this new environment. Discussions have begun within the Groupe Consultatif to encourage the evolution of an agreed common core syllabus for 
actuarial education in Europe. Possibilities for mutual co-operation in actuarial education are also being investigated through the offices of the Groupe Consultatif.

7.6. Current legislation in the UK defines the Appointed Actuary in terms of UK actuarial qualifications. It is not yet clear how this will be changed but some modification may be necessary in order to comply with the Higher Education Diplomas Directive.

7.7. As we have discussed, the legislation in the UK assumes that the individual carrying out the actuarial function will be regulated by the Institute and Faculty of Actuaries and be subject to their Professional Guidance Notes. So, it is important that migrants from other member states, who wish to carry out such functions, should apply for membership to the Institute or Faculty. The Directive would require that such individuals should be admitted as full members (subject to completion of an adaptation period of at most one year, or an aptitude test, at the choice of the migrant). They would then become subject to the full rigours of the UK professional code and set of standards - these require, inter alia, that a member should only act where he/she has sufficient knowledge and experience in relation to the work envisaged.

7.8. The Groupe Consultatif has drawn up an Agreement (April 1991) for the mutual recognition by each national association of actuaries of members of other national associations in the EC. This Agreement has now been signed by all the relevant national associations, except the Italian associations (who are inhibited from signing at present by statutory restrictions). Under this Agreement, any migrant actuary must apply for membership of the association in the country where he wishes to practise. The Agreement provides automatic full membership to anyone who is already a full member of a national actuarial association in another member state. The Agreement goes beyond the Directive in permitting, rather than requiring, associations to impose either an adaptation period or an aptitude test, at the choice of the migrant.

7.9. The Agreement will thus bring migrant actuaries directly under the professional code of the host country. As a result, it is likely that professional codes will become increasingly important throughout the $\mathrm{EC}$, along with the concept of an individual undertaking work (anywhere in the EC) for which he/she has adequate knowledge and experience.

7.10. In this new environment, the possibility of tension between the requirements of different codes of conduct may persist. Thus, the principles to be followed by the UK Appointed Actuary (as, for example, in professional guidance note GN1) are applicable to UK actuaries advising insurers overseas, even if they result in a more stringent approach than local statutory requircments. Conflicts may then arise between the UK professional code and local requirements and practice. These conflicts may increase rather than lessen when members practising abroad become, as a consequence of the Higher Education Diplomas Directive, members of a local association with a different codc of conduct.

7.11. It is worth noting that, in the competitive life insurance markets of North America, changes in the supervisory regime are tending to place more responsibility on the actuary, as previous tighter regulations have proved less able to handle product innovation. In Canada, there are moves to introduce the "Appointed Actuary" concept. This trend may also emerge in other areas.

7.12. Further information on the role of the actuary in the UK life insurance environment can be obtained from the references below, on which the author has drawn heavily. 


\section{The single market in insurance}

8.1. The Commission of the EC has been working to a timetable which aims to have the basic structure for "single market" in place before 1 January 1993. As far as life insurance is concerned, two important elements of this structure are the Life Framework Directive (LFD) and the Insurance Accounts Directive (IAD).

8.2. The proposal for the LFD was published in March 1991, following discussions which involved the Groupe Consultatif (see section 7.4), as a body representing agreed actuarial opinion across the whole of the EC.

The key components of the LFD are as follows:

(a) The principle of a single licence to carry on insurance business anywhere in the EC. Each company would be supervised only by the supervisory regime where the head office is located but would receive a licence to operate throughout the $\mathrm{EC}$, either through the establishment of branches or directly. There would be no further layers of supervision in the member states where business is being transacted.

(b) The prohibition of requirements for the prior approval or detailed notification of policy conditions, policy documentation or premium rates.

(c) The calculation of reserves should follow a set of general actuarial principles, dealing with methods of calculation and bases.

(d) General principles are laid down for the investments backing the technical reseerves, with the objectives of avoiding concentration, spreading risk and representing prudent principles of investment policy. Specifically, these investments should be chosen with due regard to the nature and duration of the underlying liabilities. There is a list of permitted types of investment (for assets backing the technical reserves) and a list of maximum percentages in individual assets or types of asset.

Components (a), (b) and (d) also feature in the draft Non-Life Framework Directive, which was published earlier.

The draft Directive was agreed by the Council of Ministers in November 1992.

8.3. The Commission's proposals for an IAD appeared in early 1987 after a long period of consultation with interested parties.

Under the proposed IAD, insurance companies would have to conform with prescribed layouts of the profit and loss account and the balance sheet and these would need to be presented to give a "true and fair view" of the financial position of the company.

The problems to be overcome in drafting an acceptable Directive on insurance company accounts are complex. These include:

(a) the different approaches in member states to the production of accounts for different audiences, for example the practice of using the same set of accounts for the shareholders and the supervisory authorities;

(b) the different approaches to the valuation of assets;

(c) the treatment of unrealised gains and losses;

(d) the treatment of reinsurance;

(e) the delayed emergence of surpluses and the inherent smoothing in the distribution of bonus for with-profits business.

The draft Directive was agreed by the Council of Ministers in June 1991. 
8.4. At the time of writing, it is not clear what the implications will be of these two Directives for the insurance markets of the different member states. Further, there are problems arising from the different approaches to the taxation of insurance premiums and insurance companies between the member states. (These problems are no different in principle from those that already exist within states regarding the taxation regimes applying to different financial institutions, for example, banks, unit trusts, pension schemes and life insurance). These mean that there is not yet in place a "level playing field" as far as the taxation treatment of life insurance is concerned. So, although the foundations for the Single Market in Insurance are now in place, doubts persist about the reality of this Market.

\section{Acknowledgements}

A preliminary version of this paper was presented at a Seminar on Productivity and Performance in Insurance at FREF in Paris on January 16 and 17, 1990. The Seminar was supported by the Geneva Association; the author also acknowledges the helpful comments received on the earlier draft by participants at the Seminar.

\section{REFERENCES}

ABBOTT, W.M. (1984), Statutory Regulation of Long Term Business, Life Insurance Monograph, $50 \mathrm{pp}$., Institute of Actuaries, London.

DAYKIN, C.D. (1992), The Developing Role of the Government Actuary's Department in the Supervision of Insurance. Journal of Institute of Actuaries, 119, 313-343.

FERGUSON, D. G. R., CROUCHER, P.E., FRANKLIN, N. A. M. et al (1989), A Single European Market for Actuaries. Journal of Institute of Actuaries, 116, 453-507 (with discussion).

JOHNSTON, E. A. (1989), The Appointed Actuary. Journal of Institute of Actuaries, 116, 27-78 (with discussion).

VAN BERLAER D. (1989), Actuarial Factors Related to Life Insurance Practices in the European Communities countries. CEA, Institute of Actuaries, Lodon. 